\title{
Local Public Investment Drivers in Peru
}

\author{
Alvaro Jimenez $^{\mathrm{a}}$, Christian Merino ${ }^{\mathrm{b}}$, Juan Carlos Sosa ${ }^{\mathrm{c}, \boldsymbol{m}}$

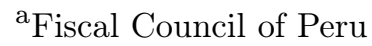 \\ $\bowtie$ alvaro.jimenez@cf.gob.pe \\ (D) 0000-0002-1333-2827 \\ ${ }^{\mathrm{b}}$ Fiscal Council of Peru \\ $\bowtie$ christian.merino@cf.gob.pe \\ ${ }^{\mathrm{c}}$ Fiscal Council of Peru \\ $\bowtie$ juancarlos.sosa@cf.gob.pe "Corresponding author
}

\begin{abstract}
Around half of Peru's public investment is made by local governments. Through the estimation of a dynamic panel data model for 1796 local governments between 2010 and 2018, we find that the most important drivers for local public investment are: (i) availability of funding sources, especially those associated to non-renewable natural resource revenues; (ii) variables associated with each local government's capacity to plan, budget and execute public investment; and (iii) political budget cycle effects, especially during the year following local elections. Furthermore, we extend our analysis by differentiating between local governments with reelected and non-reelected authorities, and by grouping local governments according to their economic size. Most of our results are shown to be robust across different specifications. Results from this paper can be used as a starting point to design mechanisms that make public investment more stable and predictable in a context where reelection banning can further deepen public investment's fall.
\end{abstract}

Article History: Received: January 212020 / Revised: September 142020 / Accepted: September 23 2020

Keywords: Public investment; Subnational governments; Political budget cycles.

JEL Classification: H70, H72, R53

\section{Acknowledgements}

We thank useful comments from Brigitt Bencich, Carlos Rojas, members of the Fiscal Council of Peru, participants from the XXXVI Meeting of Economists of the Central Bank of Peru, and two anonymous referees. Any remaining errors are our responsibility. The views expressed in this article are those of the authors and do not represent those of the Fiscal Council of Peru. A preliminary working paper (in spanish) of this article is available in the Fiscal Council's website, https://cf.gob.pe/. 


\section{Introduction and Stylized Facts ${ }^{1}$}

The decentralization process in Peru started in 2002 and gave an important boost to public investment carried out by the 1874 local governments. Local public investment increased from 0,8 percent of GDP in 2003 to 1,9 percent of GDP in 2018, peaking at 2,6 percent of GDP in 2013 (see Figure A.1). Due to this, local governments concentrated around half of the General Government's public investment during the period 2003-2018. (see Figure B.1).

Besides the importance in economic size, local public investment in Peru has particular features: i) it is atomized and highly variable, ii) it is greatly driven by political budget cycles, iii) it does not follow the dynamics of central government investment, and iv) it is mostly financed by intergovernmental transfers associated to non-renewable natural resources (NRNR transfers).

The first feature occurs because local public investment is concentrated in small short-lived investment projects and the execution of these is highly variable. Considering a sample of 95000 local public investment projects carried out between 2004 and 2017, 58 percent of the projects have an investment cycle shorter than a year with an average budget of 0,8 million soles. ${ }^{2}$ As evidence of high variability, between 2003 and 2018, local public investment featured several highs and lows, reaching a peak growth of 65,7 percent in real terms in 2006 and a minimum of $-25,4$ percent in real terms in 2015 . This feature is even more visible if we analyze the evolution of public investment of each local government individually.

The second feature about the political budget cycle has been observed in the last three municipal elections. Local public investment in municipalities with non-reelected authorities reduced in 0,$04 ; 0,51$ and 0,61 percentage points (p.p.) of GDP during the municipal elections of 2006; 2010 and 2014; respectively (see Figure B.3). This could be partly explained because only around one fifth of local authorities were reelected.

Similarly, the third feature about the differences between the dynamic of local public investment and central government investment can be seen in aggregate terms. The work of Rojas and Vassallo (2018) shows that the fiscal impulse of local capital expenditure has a negative correlation with the fiscal impulse of national capital expenditure in recent years (2013-2017). This has an impact in macro-fiscal policy because it limits the policymaker's capacity to change public spending on a discretionary basis.

Finally, around 39 percent of local public investment was financed by NRNR transfers between 2009 and 2018. However, this participation has decreased in recent years due to the fall of commodity prices between 2012 and 2016. This reduction has given more importance to other funding sources like ordinary transfers and credit operations, whose participation has increased in recent years, unlike the directly collected resources (tax and non-tax revenues raised locally), which, in spite of being the most stable funding source, only represents 5 percent of local public investment funding.

The economic size and the particularities of local public investment in Peru make the study

\footnotetext{
${ }^{1}$ Appendices A and B provide useful graphs and data used to support this introduction.

${ }^{2}$ In addition, 99 percent of the projects managed by the local governments only required studies at the profile level, which implies an investment of less than S/ 1,2 million (according to the General Directive of the National System of Public Investment).
} 
of local public investment drivers a relevant topic. We consider that results of this paper can be used to design policy strategies to make future local public investment growth more predictable, sustainable, and equitable. Due to changes in the legal framework regarding municipal reelection in 2018, public debate has centered in the macroeconomic and fiscal role of public investment and the effects of reelection banning ${ }^{3}$ in the short and long term. We believe this paper can contribute to that debate.

To accomplish this objective, we first identify local public investment drivers through a literature review and group them into three categories: (i) variables associated to availability of funding sources; (ii) variables associated to each local government management capacity; and (iii) variables associated to the effect of political budget cycle. These variables are then incorporated in an empirical panel data model.

Our results show that the three groups of drivers impact local public investment in different degrees. We find that funding sources, mainly NRNR transfers, are the most important determinants of local public investment. Regarding management capacity, the reelection of municipal authorities and their experience in the charge have an important positive impact in local public investment. Finally, results about the political budget cycle are consistent with our expectations, local public investment plummets during the first year after the election and quickly recovers in the second year. The fourth year after the election, local public investment is higher compared to the third year. Our main results are found to be robust across different specifications with some small differences according to economic size and continuous reelection or not.

The rest of the document is organized as follows. The second section shows the literature review focusing on the drivers of the local public investment. The third section presents the empirical methodology. The fourth section presents the main results, while the fifth section shows robustness analysis. Finally, the sixth section concludes and gives policy recommendations.

\section{Literature Review ${ }^{4}$}

In this section, we make an overview of other studies that research local public investment drivers. As we have pointed out before, we group drivers in three main categories: (i) availability of funding sources, (ii) management capacity, and (iii) political budget cycle effects.

\subsection{Availability of Funding Sources}

Preferences for using a specific funding source for investment are essentially determined by inherent characteristics to each local government. Empirical literature emphasizes the differentiated effect of each funding source. We primarily focus on three groups of funding sources: i) transfers from the National Government that can only be used to finance public investment, ii) directly collected resources by local governments and, iii) resources from long-term credit operations, mainly aimed at public investment.

\footnotetext{
${ }^{3}$ According to law 30305, Law of reform of articles 191, 194 and 203 of the Political Constitution of Peru about not immediate reelection of authorities of regional governments and mayors.

${ }^{4}$ In addition to the literature review, appendix C provides a brief budgetary and legal framework about public investment funding in Peru.
} 
The first group of funding sources are the transfers from National Government that can only be used to finance public investment, within this group we have the capital transfers and NRNR transfers. Regarding capital transfers, Chortareas et al. (2016) and Goeminne and Smolders (2014) find that increases in this type of transfers have a positive effect on public investment for local governments of Greece and Belgium, respectively. In the case of the local governments of Spain, Balmas (2015) finds that as these transfers grow as a proportion of local governments revenues, a greater amount of public investment is performed. Lastly, for local governments of Portugal, Veiga and Veiga (2007) find a positive effect on public investment of both capital transfers and ordinary transfers.

Regarding NRNR transfers, Lastra (2017) finds that these transfers are the most important funding source for local public investment in Peru, leaving in the background other sources like ordinary resources, FONCOMUN, and directly collected resources. Likewise, Pebe et al. (2017) find that local governments with a greater availability of NRNR transfers tend to spend higher amounts of resources in public investment.

In the case of the directly collected resources by local governments, there is consensus regarding sign and significance, but studies differ in terms of impact size on local public investment. Chortareas et al. (2016) find that an increase in revenues has a positive and significant effect in local public investment, but relatively smaller than those obtained by intergovernmental fiscal transfers. On contrast, Balmas (2015) finds a relatively large and significant effect of these resources for local governments in Poland. Lastly, Lastra (2017) finds that directly collected resources by local governments in Peru become more important to finance public investment as the local government is larger. ${ }^{5}$

Finally, empirical literature shows that the effect of credit operations in local public investment differs across countries. Balmas (2015) does not find a significant effect of credit operations over local public investment in Spain and Poland; whereas Goeminne and Smolders (2014) find that local public investment in Belgium strongly depends on credit operations as a funding source.

\subsection{Management Capacity}

Local government authorities not only face budget constraints to carry out an investment project, they also have restrictions in their capacities to manage available resources. For the Peruvian case, Aragón and Casas (2009) point out that usage of funding sources for capital expenditure have additional regulations that must be complied, linked to the identification of the problem, the design and size of the public investment project, among others.

To accomplish with this regulation, it is necessary for the local government to have an adequate staff of trained personnel to carry out the respective tasks with the necessary technological tools. Aragon and Casas (2009) consider a variable called assistance ${ }^{6}$ as an approach to management capacity and find that local governments that request assistance are those with the lowest level

\footnotetext{
${ }^{5}$ To differentiate local governments size, the author considers the classification used in the incentive plan for municipal management.

${ }^{6}$ The variable is defined as the need for assistance for the formulation and evaluation of public investment projects, obtained from the National Registry of Municipalities (RENAMU).
}

\section{PUCP}


of public investment. In addition, Díaz (2018) notes that restrictions on management capacities are accentuated in rural local governments, where 30 percent of these were not able to correctly formulate their demand for infrastructure between 2010 and 2016.

Lastra (2017) includes four variables associated with management capacity. The first is the same variable assistance, which has a negative effect on local public investment as in Aragón and Casas (2009). The second variable is the local government's access to the budget computer system, which has a positive effect over local public investment. The third variable is internet access by the local government, whose effect is also positive, but not significant. Finally, the author considers a dummy variable that takes the value of one when there are more than two professionals working in the local government. For this last variable, the author finds a positive but not significant effect.

It is worth noting that authorities at any level of government acquire experience through time. In this way, years in office will partly reflect their management skills. Several studies show local public investment falls the year after the municipal election due to the entry of new authorities (Goeminne and Smolders, 2014; Reid, 1998). Therefore, local governments with authorities that accumulates a greater number of years of experience should have smaller reductions of public investment the year following elections.

\subsection{Political Budget Cycle}

According to Nordhaus (1975), the political budget cycle consists in the strategic behavior from the incumbent government authority in periods close to the elections. The incumbent follows an expansionary policy; by increasing public spending, reducing taxes, or increasing transfers; with the objective of convincing voters that they are holding an efficient work; and thus, influence the decision of the voters.

From a theoretical point of view, there are three types of models that can explain the strategic behavior. The first model developed by Nordhaus (1975) consists of a model where voters are myopic and have adaptive expectations. However, this is criticized by Veiga and Veiga (2007) who highlight the weakness of this kind of models where voters are deceived by the incumbent authority, which always shows the same behavior in each electoral period.

The second type of models seeks to overcome this criticism by incorporating the fact that voters have rational expectations (Rogoff, 1990; Rogoff and Sibert, 1988). In this class of models, myopia of the voters is replaced by the existence of asymmetric information, since the incumbent authority has better information about its own level of competence. Voters do not observe this directly, but rather infer it from fiscal policy carried out by the government (Drazen and Eslava, 2010).

The third type of model developed by Drazen and Eslava (2010) shows that citizens prefer certain categories of public spending the most. Thus, the incumbent authority recomposes public spending during electoral periods to signal voters that their preferences have been aligned. Under this approach, the political cycle takes the form of a recomposition of public spending without affecting the levels of fiscal deficit, to which the voters are adverse.

From an empirical point a view, we find two facts in the empirical literature. The first consists 
in the fact that public investment increases in periods prior to an electoral process (Balmas, 2015; Goeminne and Smolders, 2014; Reid, 1998). This occurs either during the year of the elections (Balmas, 2015) or in the year prior to them (Guzmán, 2015) because it increases the authority's probability of reelection (Guzmán, 2015; Balaguer-Coll et al., 2015). ${ }^{7}$ In addition, this increase in investment can occur in those sectors that are most visible to the voters, either through an increase in the fiscal deficit (Veiga and Veiga, 2007) or a recomposition of public spending (Drazen and Eslava, 2010).

The second consist is the presence of the political budget cycle in both democratic and authoritarian regimes. This is found by Guo (2009) who, in the case of China's local governments, finds that the strategic behavior of the incumbent authority is mainly focused on the development of their political career, even in the absence of competitive elections.

Finally, we list other drivers different from those described in previous paragraphs. The literature considers variables that measure economic activity at the local level, which have an effect on public investment like the unemployment rate (Balmas, 2015; Goeminne and Smolders, 2014; Reid, 1998) or the level of gross domestic product (Schneider, 2010). Lastly, to capture the size of a local government, other documents consider the population density (Balmas, 2015; Veiga and Veiga, 2007) and the number of voters (Goeminne and Smolders, 2014).

\section{Methodology}

We estimate a balanced dynamic panel data model for 1796 local governments through years 2010-2018. ${ }^{8}$ For this purpose, we use the two-stage estimator proposed by Arellano and Bover (1995) and Blundell and Bond (1998), ${ }^{9}$ correcting the estimator bias according to Windmeijer (2005). The method used is a generalization of the Arellano and Bond (1991) estimator which allows us to incorporate time-invariant variables such as Hausman and Taylor (1981) in a dynamic context.

Specifically, we estimate parameters from the following equation:

$$
y_{i, t}=c+\alpha y_{i, t-1}+X_{i t}^{\prime} \beta+Z_{i}^{\prime} \gamma+W_{t} \delta+u_{i t},
$$

where:

$$
\begin{aligned}
& i=1, \ldots, 1796 \\
& t=2010, \ldots, 2018
\end{aligned}
$$

\footnotetext{
${ }^{7}$ In addition, increases in public investment are greater in those countries where elections are not predetermined every certain number of years (Shi and Svensson, 2006).

${ }^{8}$ We discard 78 local governments because they were recently created or because they do not have complete information for all the variables used in this analysis. Their exclusion does not change our main results as they represent only around 4 percent of total local public investment in 2018.

${ }^{9}$ The two-stage estimator uses the lags of the dependent variable in first differences as instruments in the equation in levels, in addition to the lagged values of the dependent variable, which are used as instruments in the equation in first differences. For more details about the methodology, we suggest Baltagi (2013) and Hashem (2015).
} 
With:

$$
\begin{gathered}
u_{i t}=\mu_{i}+v_{i t} \\
E\left(\mu_{i}\right)=E\left(v_{i t}\right)=E\left(\mu_{i} v_{i t}\right)=0 .
\end{gathered}
$$

The variable $y_{i, t}$ represents the dependent or endogenous variable of the model; which depends on an intercept $c$, its own lag weighted by the coefficient $\alpha$; and three types of dependent or exogenous variables weighted by coefficient vectors $\beta, \gamma$ and $\delta$, respectively. The first class of dependent variables $X_{i t}$ change over time and for each local government. The second class of dependent variables $Z_{i}$ is time-invariant but different across local governments. The third class of the dependent variables $W_{t}$ can change over time but remains constant across local governments. Finally, the residual $u_{i t}$ is composed of an individual error $\mu_{i}$ and an idiosyncratic error $v_{i t}$, where both are independent between each other.

For our empirical estimation, the dependent variable is the logarithm of gross capital formation in millions of soles. ${ }^{10}$ The independent variables are divided into three groups according to the classification discussed in the previous section. Table 1 summarizes all variables used and information sources.

The first group of independent variables reflect the availability of funding sources. Variables named NRNR transfers, capital transfers, credit operations and directly collected resources are included in this group. These variables are included in logarithms, and in the case of NRNR transfers, the lagged value was also considered as part of the estimation. Likewise, these variables are part of the variables that change across local governments and over time.

The second group of independent variables reflect management capacity. We include in this group two dummy variables named technical assistance and training requirement. Both variables take the value of one when the local government indicates the need for technical assistance and training requirement in the formulation and evaluation of public investment projects. Another variable within this category is called internet access, which takes the value of one when the local government has access to internet. Finally, we include two variables called reelections and experience. The variable reelection is a dummy variable which takes the value of one in the years 2011 or 2015 when the mayor of a local government was reelected. The variable experience is a continuous variable that reflects the years of experience a mayor has in the same municipality. All these variables are part of the variables that change across local governments and over time.

The third group of independent variables reflect the political budget cycle. We include in this group three dummy variables called year1, year2 and year3. The first dummy variable takes the value of one during the first year of the term of the mayor, while second dummy variable takes the value of one during the second year in government. Likewise, the third dummy variable takes the value of one during the third year in government. These variables change over time but are the same for all local governments.

The final group of independent variables are control variables. The first variable is the nonprimary GDP, which captures the evolution of the economic activity in the region. This variable

\footnotetext{
${ }^{10}$ Stationarity of variables used in our estimation was tested by the unit root test of Harris-Tzavalis (Harris and Tzavalis, 1999). The null hypothesis of unit root in the panel was rejected for dependent and independent variables.
} 
Table 1

Variable description.

\begin{tabular}{|c|c|c|c|c|}
\hline Variable & Details & Source & Unit & Transformation \\
\hline \multicolumn{5}{|l|}{ Dependent variable } \\
\hline Gross capital formation & $\begin{array}{l}\text { Public investment executed by local govern- } \\
\text { ments. }\end{array}$ & $\mathrm{MEF}$ & Soles & Logarithmic \\
\hline \multicolumn{5}{|l|}{ Independent variables } \\
\hline \multicolumn{5}{|l|}{ Funding sources } \\
\hline NRNR transfers & $\begin{array}{l}\text { Transfers for the extraction of non-renewable } \\
\text { natural resources (canon, royalties, sobre- } \\
\text { canon and FOCAM). }\end{array}$ & $\mathrm{MEF}$ & Soles & Logarithmic \\
\hline Capital transfers & $\begin{array}{l}\text { Transfers of ordinary resources for capital } \\
\text { spending. }\end{array}$ & MEF & Soles & Logarithmic \\
\hline Credit operations & $\begin{array}{l}\text { Long-term operations assigned to finance } \\
\text { public investment. }\end{array}$ & MEF & Soles & Logarithmic \\
\hline Directly collected resources & $\begin{array}{l}\text { Revenues collected by the local governments } \\
\text { (tax and non-tax revenues). }\end{array}$ & $\mathrm{MEF}$ & Soles & Logarithmic \\
\hline \multicolumn{5}{|l|}{ Management capacity } \\
\hline Technical assistance & $\begin{array}{l}\text { Dummy variable that takes the value of } 1 \\
\text { when the local government indicates the need } \\
\text { of technical assistance for the formulation } \\
\text { and evaluation of public investment projects. }\end{array}$ & RENAMU & - & Dummy variable \\
\hline Training requirement & $\begin{array}{l}\text { Dummy variable that takes the value of } 1 \\
\text { when the local government indicates the need } \\
\text { of training requirement for the formulation } \\
\text { and evaluation of public investment projects. }\end{array}$ & RENAMU & - & Dummy variable \\
\hline Internet access & $\begin{array}{l}\text { Dummy variable that takes the value of } 1 \\
\text { when the local government has access to the } \\
\text { internet. }\end{array}$ & RENAMU & - & Dummy variable \\
\hline Re-election & $\begin{array}{l}\text { Dummy variable which take the value of } 1 \text { in } \\
\text { the years } 2011 \text { and } 2015 \text { when the mayor of } \\
\text { a local government was re-elected. }\end{array}$ & RENAMU & - & Dummy variable \\
\hline Experience & $\begin{array}{l}\text { Continuous variable that reflects the number } \\
\text { of years of experience the mayor has in the } \\
\text { same municipality. }\end{array}$ & RENAMU & Years & - \\
\hline \multicolumn{5}{|l|}{ Political budget cycle } \\
\hline Year1 & $\begin{array}{l}\text { Dummy variable takes the value of } 1 \text { during } \\
\text { the first year of the term of the mayor. }\end{array}$ & - & - & Dummy variable \\
\hline Year2 & $\begin{array}{l}\text { Dummy variable takes the value of } 1 \text { during } \\
\text { the second year of the term of the mayor. }\end{array}$ & - & - & Dummy variable \\
\hline Year3 & $\begin{array}{l}\text { Dummy variable takes the value of } 1 \text { during } \\
\text { the third year of the term of the mayor. }\end{array}$ & - & - & Dummy variable \\
\hline \multicolumn{5}{|l|}{ Control variables } \\
\hline Non-primary GDP & $\begin{array}{l}\text { Regional GDP of the following sectors: non- } \\
\text { primary manufacturing, electricity and wa- } \\
\text { ter, construction, commerce, and services. }\end{array}$ & INEI & Soles & Logarithmic \\
\hline Urban & $\begin{array}{l}\text { Dummy variable that takes the value of } 1 \\
\text { when more than fifty percent of properties } \\
\text { are ubicated in urban areas. }\end{array}$ & INEI & - & Dummy variable \\
\hline Access to potable water & $\begin{array}{l}\text { Dummy variable that takes the value of } 1 \\
\text { when more than fifty percent of properties } \\
\text { have access to a public grid of potable water. }\end{array}$ & INEI & - & Dummy variable \\
\hline Access to public lighting & $\begin{array}{l}\text { Dummy variable that takes the value of } 1 \\
\text { when more than fifty percent of properties } \\
\text { have access to a public lighting network. }\end{array}$ & INEI & - & Dummy variable \\
\hline
\end{tabular}

Notes: MEF: Ministry of Economics and Finance of Peru (Ministerio de Economía y Finanzas del Perú). Systematized financial data was provided by the General Directorate of Macroeconomic Policy and Fiscal Decentralization.

RENAMU: National Registry of Municipalities Survey (Registro Nacional de Municipalidades).

INEI: National Institute of Statistics and Informatics of Peru database. (Instituto de Estadística e Informática del Perú). 
is included in logarithms, and changes across regions and over time. The rest of control variables are dummy variables called urban, access to potable water, and access to public lighting. The variable urban takes the value of one when more than fifty percent of properties in the local government are in urban areas. The variable access to potable water takes the value of one when more than fifty percent of properties have access to a public grid of potable water.

Finally, the variable access to public lighting takes the value of one when more than fifty percent of properties have access to a public lighting network. These variables change across local governments but remain constant over time.

\section{Results}

Estimation results are shown in Table 2. All four different specifications include a constant and the lagged dependent variable. The first specification includes the funding sources of local public investment, the second specification adds variables associated to the management capacity and the third specification incorporates variables associated to the political budget cycle. The fourth specification adds the control variables.

Through the four specifications we find that the coefficient associated to the lag of gross capital formation (GCF) has a relatively low value, between 0,29 and 0,34 . This result shows that local public investment in Peru has low persistence, consistent with the fact that local public investment is atomized and concentrated in short-lived projects as described in the introduction. Everything else constant, high levels of local public investment do not seem to persist over time.

Results regarding funding sources are as expected. The coefficients associated to NRNR transfers are found positive and significant both in a contemporary way and in its first lag. The significance of the contemporary coefficient across the four specifications shows the relevance of this factor as one of the major funding sources of local public investment. Furthermore, the significance of the coefficient associated to lagged NRNR transfers is evidence that resources not fully executed by the local governments during the year the transfer is received are saved and then executed in following years (unused resources are commonly called saldos de balance in Peru).

Contemporaneous capital transfers and credit operations have positive and significant coefficients in the four specifications. ${ }^{11}$ Results regarding capital transfers are consistent with the fact that these resources return to the Central Government if public investment is not executed during the fiscal year in which they were transferred. Regarding credit operations, coefficients are found to be small in comparison with the rest of funding sources. This result can be associated to the fact that only around 15 percent of local governments use credit operations to finance public investment. ${ }^{12}$

Directly collected resources have positive and significant coefficients, but we consider that point estimates could be slightly overestimated in some specifications. As shown in the next section, coefficient values are significantly reduced in medium and small local governments. Our

\footnotetext{
${ }^{11}$ Preliminary estimations considered lagged values of capital transfers and credit operations but estimated coefficients where found to be non-significant.

${ }^{12}$ Within these local governments, credit operations represent only around 10 percent of their total revenues.
} 


\section{Table 2}

Public investment drivers estimation.

\begin{tabular}{|c|c|c|c|c|c|}
\hline \multicolumn{2}{|c|}{$\begin{array}{l}\text { Dependent variable: } \\
\text { Gross capital formation }(\mathrm{GCF})\end{array}$} & Model 1 & Model 2 & Model 3 & Model 4 \\
\hline \multirow{6}{*}{$\begin{array}{l}\text { Funding } \\
\text { sources } \\
\text { variables }\end{array}$} & GCF $(-1)$ & $\begin{array}{c}0,337^{* * *} \\
(0,0164)\end{array}$ & $\begin{array}{c}0,294^{* * *} \\
(0,0162)\end{array}$ & $\begin{array}{c}0,308^{* * *} \\
(0,0146)\end{array}$ & $\begin{array}{l}0,310^{* * *} \\
(0,0251)\end{array}$ \\
\hline & NRNR transfers & $\begin{array}{c}0,0927^{* * *} \\
(0,0149)\end{array}$ & $\begin{array}{c}0,106^{* * *} \\
(0,0152)\end{array}$ & $\begin{array}{l}0,106^{* * *} \\
(0,0147)\end{array}$ & $\begin{array}{c}0,0782^{* * *} \\
(0,0147)\end{array}$ \\
\hline & NRNR transfers $(-1)$ & $\begin{array}{c}0,0745^{* * *} \\
(0,0147)\end{array}$ & $\begin{array}{c}0,0751^{* * *} \\
(0,0144)\end{array}$ & $\begin{array}{c}0,0752^{* * *} \\
(0,0133)\end{array}$ & $\begin{array}{c}0,0418^{* * *} \\
(0,0132)\end{array}$ \\
\hline & Capital transfers & $\begin{array}{c}0,0478^{* * *} \\
(0,00170)\end{array}$ & $\begin{array}{c}0,0480^{* * *} \\
(0,00162)\end{array}$ & $\begin{array}{c}0,0493^{* * *} \\
(0,00149)\end{array}$ & $\begin{array}{r}0,0507^{* * *} \\
(0,00154)\end{array}$ \\
\hline & Credit operations & $\begin{array}{c}0,00579^{* * *} \\
(0,00209)\end{array}$ & $\begin{array}{c}0,00704^{* * *} \\
(0,00196)\end{array}$ & $\begin{array}{c}0,00807^{* * *} \\
(0,00178)\end{array}$ & $\begin{array}{c}0,00852^{* * *} \\
(0,00176)\end{array}$ \\
\hline & Directly collected resources & $\begin{array}{c}0,0814^{* * *} \\
(0,0133)\end{array}$ & $\begin{array}{c}0,0780^{* * *} \\
(0,0126)\end{array}$ & $\begin{array}{c}0,0745^{* * *} \\
(0,0115)\end{array}$ & $\begin{array}{c}0,0573^{* * *} \\
(0,0101)\end{array}$ \\
\hline \multirow{5}{*}{$\begin{array}{l}\text { Management } \\
\text { capacity } \\
\text { variables }\end{array}$} & Technical assistance & & $\begin{array}{c}-0,0455^{* *} \\
(0,0213)\end{array}$ & $\begin{array}{c}-0,0461^{* *} \\
(0,0189)\end{array}$ & $\begin{array}{l}-0,0358^{*} \\
(0,0185)\end{array}$ \\
\hline & Training requirement & & $\begin{array}{l}-0,0310 \\
(0,0211)\end{array}$ & $\begin{array}{l}-0,0292 \\
(0,0190)\end{array}$ & $\begin{array}{c}-0,0398^{* *} \\
(0,0185)\end{array}$ \\
\hline & Internet access & & $\begin{array}{c}0,0871^{* * *} \\
(0,0323)\end{array}$ & $\begin{array}{c}0,0805^{* * *} \\
(0,0289)\end{array}$ & $\begin{array}{l}0,0485^{*} \\
(0,0284)\end{array}$ \\
\hline & Re-election & & $\begin{array}{c}-0,0667^{* *} \\
(0,0285)\end{array}$ & $\begin{array}{c}0,180^{* * *} \\
(0,0351)\end{array}$ & $\begin{array}{c}0,202^{* * *} \\
(0,0340)\end{array}$ \\
\hline & Experience & & $\begin{array}{c}0,0483^{* * *} \\
(0,00441)\end{array}$ & $\begin{array}{r}0,0158^{* * *} \\
(0,00551)\end{array}$ & $\begin{array}{l}0,0123^{* *} \\
(0,00552)\end{array}$ \\
\hline \multirow{3}{*}{$\begin{array}{l}\text { Political } \\
\text { budget cycle }\end{array}$} & Year1 & & & $\begin{array}{c}-0,251^{* * *} \\
(0,0235)\end{array}$ & $\begin{array}{c}-0,264^{* * *} \\
(0,0229)\end{array}$ \\
\hline & Year2 & & & $\begin{array}{c}0,0338^{* *} \\
(0,0156)\end{array}$ & $\begin{array}{c}0,0341^{* *} \\
(0,0162)\end{array}$ \\
\hline & Year3 & & & $\begin{array}{c}-0,0801 * * * \\
(0,0149)\end{array}$ & $\begin{array}{c}-0,0881^{* * *} \\
(0,0152)\end{array}$ \\
\hline \multirow{7}{*}{$\begin{array}{l}\text { Control } \\
\text { variables }\end{array}$} & Non-primary GDP & & & & $\begin{array}{c}0,197^{* * *} \\
(0,0613)\end{array}$ \\
\hline & Urban & & & & $\begin{array}{c}0,939^{* * *} \\
(0,328)\end{array}$ \\
\hline & Access to potable water & & & & $\begin{array}{c}2,025 \\
(1,690)\end{array}$ \\
\hline & Access to public lighting & & & & $\begin{array}{l}3,917^{*} \\
(2,022)\end{array}$ \\
\hline & Constant & $\begin{array}{c}6,245^{* * *} \\
(0,330)\end{array}$ & $\begin{array}{c}6,568^{* * *} \\
(0,322)\end{array}$ & $\begin{array}{c}6,546^{* * *} \\
(0,296)\end{array}$ & $\begin{array}{l}-2,877 \\
(2,475)\end{array}$ \\
\hline & Observations & 15837 & 15837 & 15837 & 15837 \\
\hline & Number of local governments & 1796 & 1796 & 1796 & 1796 \\
\hline
\end{tabular}

Notes: Standard errors corrected by Windmeijer (2005) are in parenthesis.

***, ** and ${ }^{*}$ denote significance to 1,5 and 10 percent, respectively. (-1) indicates a lagged variable from previous year. 
explanation is that this variable could be correlated with management capacity, ${ }^{13}$ as the value of the coefficient is reduced in specifications where management capacity variables are included.

Results regarding management capacity are mostly as expected. Variables technical assistance and training requirement have negative coefficients in specifications where they are considered, but joint significance is found only in the last model. An interpretation of this result is founded in Aragón and Casas (2009), who show that local governments that request technical assistance (or training requirement) for the formulation and evaluation of public investment projects have a lower propensity to execute capital expenditure. In the same manner, variable internet access is significant and has a positive sign in the specifications where it is considered.

Variables reelection and experience have the expected effect in the last two specifications. The coefficient associated to re-election indicates that local governments where majors were reelected have between 18 and 20 percent more public investment compared to local governments where majors were not reelected. The coefficient associated to experience reinforces the last result. For each additional year in charge, local public investment increases between 1,2 and 1,5 percent. Results regarding reelection and experience variables show that authorities with several years in charge do not have to go through a learning curve, unlike the new authorities.

Finally, results regarding political budget cycle are also mostly as expected and are reflected in coefficients associated to variables year1, year2 and year3. The coefficient associated to the first year after the municipal elections (year 1 ) shows that public investment plummets, dropping around 25 percent in comparison to the previous year. The contraction in public investment is recovered during the second year (year2), either by the experience acquired by the new authorities or by a rebound effect. Lastly, during the third year in charge (year3), the value of the coefficient is negative, which can be explained by the fact that the growth rate of the public investment was high during the previous year (second year) ${ }^{14}$ or because investment in the last year of the political cycle is expected to rise in comparison of the previous (third) year.

\section{Robustness Analysis}

In this section, we present two robustness analysis to evaluate the sensitivity of our main results considering the last specification used in previous section. The first exercise considers a sub-sample estimation differentiating between reelected and non-reelected local governments. The second exercise also considers a sub-sample estimation, grouping local governments by their economic size according to the clustering analysis in Jiménez and Montoro (2018).

\subsection{Reelected and Non-Reelected Sub-Sample Estimation}

To isolate the political budget cycle from the effects of reelection of local authorities we compare two estimations. The first estimation considers only 108 local governments whose authorities were reelected in both 2010 and 2014 municipal elections. The second estimation

\footnotetext{
${ }^{13}$ Local governments with greater directly collected resources are generally those that have more capacities to collect and manage tax and non-tax revenues.

${ }^{14}$ This fact can also be seen in the Figure B.2a in the appendix, where the growth rate of public investment during the third year (for instance in 2008 and 2013) was smaller than previous year.
} 


\section{Table 3}

Sub-sample estimation of reelected and non-reelected local governments.

\begin{tabular}{|c|c|c|c|}
\hline \multicolumn{2}{|c|}{$\begin{array}{l}\text { Dependent variable: } \\
\text { Gross capital formation (GCF) }\end{array}$} & \multirow{2}{*}{$\begin{array}{c}\text { Local government with } \\
\text { reelected authorities } \\
\begin{array}{c}0,264^{* * *} \\
(0,0911)\end{array}\end{array}$} & \multirow{2}{*}{$\begin{array}{c}\text { Local government with } \\
\text { non-reelected authorities } \\
0,244^{* * *} \\
(0,0312)\end{array}$} \\
\hline \multirow{7}{*}{$\begin{array}{l}\text { Funding } \\
\text { sources } \\
\text { variables }\end{array}$} & $\operatorname{GCF}(-1)$ & & \\
\hline & NRNR transfers & $\begin{array}{c}0,166^{* * *} \\
(0,0496)\end{array}$ & $\begin{array}{c}0,0512^{* * *} \\
(0,0178)\end{array}$ \\
\hline & NRNR transfers $(-1)$ & $\begin{array}{c}0,0978 \\
(0,0635)\end{array}$ & $\begin{array}{c}0,0337^{* *} \\
(0,0150)\end{array}$ \\
\hline & Capital transfers & $\begin{array}{r}0,0460^{* * *} \\
(0,00507)\end{array}$ & $\begin{array}{c}0,0491^{* * *} \\
(0,00194)\end{array}$ \\
\hline & Credit operations & $\begin{array}{c}0,00217 \\
(0,00687)\end{array}$ & $\begin{array}{c}0,00855^{* * *} \\
(0,00215)\end{array}$ \\
\hline & Directly collected resources & $\begin{array}{l}0,0611^{*} \\
(0,0326)\end{array}$ & $\begin{array}{c}0,0680^{* * *} \\
(0,0131)\end{array}$ \\
\hline & Technical assistance & $\begin{array}{l}-0,0108 \\
(0,0592)\end{array}$ & $\begin{array}{l}-0,0339 \\
(0,0232)\end{array}$ \\
\hline \multirow{3}{*}{$\begin{array}{l}\text { Management } \\
\text { capacity } \\
\text { variables }\end{array}$} & Training requirement & $\begin{array}{l}-0,0736 \\
(0,0604)\end{array}$ & $\begin{array}{c}-0,0472^{* *} \\
(0,0235)\end{array}$ \\
\hline & Internet access & $\begin{array}{c}0,0671 \\
(0,0928)\end{array}$ & $\begin{array}{c}0,0490 \\
(0,0359)\end{array}$ \\
\hline & Experience & $\begin{array}{l}-0,0273 \\
(0,0211)\end{array}$ & $\begin{array}{c}0,00550 \\
(0,00898)\end{array}$ \\
\hline \multirow{3}{*}{$\begin{array}{l}\text { Political } \\
\text { budget cycle }\end{array}$} & Year1 & $\begin{array}{l}-0,0839 * \\
(0,0507)\end{array}$ & $\begin{array}{c}-0,268^{* * *} \\
(0,0304)\end{array}$ \\
\hline & Year2 & $\begin{array}{l}-0,00628 \\
(0,0547)\end{array}$ & $\begin{array}{c}0,0116 \\
(0,0241)\end{array}$ \\
\hline & Year3 & $\begin{array}{r}-0,136^{* *} \\
(0,0571)\end{array}$ & $\begin{array}{c}-0,0861^{* * *} \\
(0,0197)\end{array}$ \\
\hline \multirow{7}{*}{$\begin{array}{l}\text { Control } \\
\text { variables }\end{array}$} & Non-primary GDP & $\begin{array}{l}0,980^{*} \\
(0,533)\end{array}$ & $\begin{array}{l}0,198^{* *} \\
(0,0805)\end{array}$ \\
\hline & Urban & $\begin{array}{l}-0,270 \\
(0,704)\end{array}$ & $\begin{array}{c}1,261^{* *} \\
(0,490)\end{array}$ \\
\hline & Access to potable water & $\begin{array}{l}-1,098 \\
(2,054)\end{array}$ & $\begin{array}{c}0,906 \\
(3,334)\end{array}$ \\
\hline & Access to public lighting & $\begin{array}{c}1,663 \\
(4,525)\end{array}$ & $\begin{array}{c}5,272 \\
(3,462)\end{array}$ \\
\hline & Constant & $\begin{array}{r}-16,25^{*} \\
(9,813)\end{array}$ & $\begin{array}{l}-2,095 \\
(4,578)\end{array}$ \\
\hline & Observations & 949 & 9442 \\
\hline & Number of local governments & 108 & 1067 \\
\hline
\end{tabular}

Notes: Standard errors corrected by Windmeijer (2005) are in parenthesis.

$* * *, * *$ and $*$ denote significance to 1,5 and 10 percent, respectively. $(-1)$ indicates a lagged variable from previous year.

considers 1067 local governments whose authorities were not reelected in either 2010 or 2014 . The results of our estimations are presented in Table 3. 
Considering only reelected local governments, we still find a negative coefficient associated to the first year of mandate (year1), albeit with a much smaller value and less significance. In contrast, considering never reelected local government results in a much more pronounced fall in public investment. This result is explained by the fact that during the year after municipal elections, local public investment falls in both reelected and non-reelected local governments ${ }^{15}$, but the fall in the latter group is greater as they always have to go through a learning curve after each election.

Coefficients for year2 are found to be non-significant in both estimations. This means that investment levels rebound from the fall in the first year towards end of the mandate levels, independently of being a reelected authority or not. On the other hand, coefficients associated to year3 is found to be negative and significant in both estimations. This result could occur because of difficulties to maintain the pace of public investment after the second year of mandate or because public investment on the last year of mandate is expected to rise.

Despite magnitude differences in the estimation considering only governments that have been reelected twice, political budget cycle effects are shown to be robust. Public investment falls in the first year of mandate, even when an authority has been reelected, and rebounds in the second year. The third year of mandate exhibits lower execution of public investment, but this could signal an increase in the last year of mandate.

\subsection{Economic Size Clustering Analysis}

According to Torero and Valdivia (2002), local governments in Peru have features that reflect the high heterogeneity that exists between them. In this regard, we divided our sample of 1794 local governments following the cluster grouping proposed by Jiménez and Montoro (2018). ${ }^{16}$ Thus, we can categorize local governments into three clusters according to their economic size ${ }^{17}$ large local governments, medium local governments, and small local governments. Results for each one of these groups are shown in Table 4.

The first result shows that low persistence of GCF remains even when local governments are separated into three groups. In the case of the variables associated with funding sources, we found the expected results. NRNR transfers remain a very important funding source, especially for medium local governments. Regarding the rest of funding sources, we find capital transfers maintain sign and significance of the coefficient across the three groups but point estimates are higher when considering small local governments. Credit operations keep the expected sign, but the result is not significant in medium local governments; whereas in large local governments the variable is more important reflecting their capacity to borrow. Directly collected resources also exhibit the expected sign, but it is only significant in small local governments.

In the case of management capacity variables such as reelection and experience we have a

\footnotetext{
${ }^{15}$ This fact also can be seen in aggregate terms in the Figure B.2 of the appendix.

${ }^{16}$ The authors divide 1861 subnational governments (regional and local) into four clusters considering three factors: economic size, degree of indebtment, and the dependence of NRNR revenues.

${ }^{17}$ Unlike the authors, we only consider three clusters instead of four, as the "very large" category mostly groups Regional Governments. The only local government found in this group is the Metropolitan Municipality of Lima so for the purpose of this paper, we have relocated it to the cluster of large governments.
} 


\section{Table 4}

Estimation of local public investment drivers by economic size clusters.

\begin{tabular}{|c|c|c|c|c|}
\hline $\begin{array}{l}\text { Dependent variable: } \\
\text { Gross capital formation }(\mathrm{GCF})\end{array}$ & & $\begin{array}{l}\text { Large local } \\
\text { governments }\end{array}$ & $\begin{array}{l}\text { Medium local } \\
\text { governments }\end{array}$ & $\begin{array}{l}\text { Small local } \\
\text { governments }\end{array}$ \\
\hline & $\operatorname{GCF}(-1)$ & $\begin{array}{l}0,165^{* *} \\
(0,0829)\end{array}$ & $\begin{array}{l}0,341^{* * *} \\
(0,0979)\end{array}$ & $\begin{array}{l}0,280^{* * *} \\
(0,0207)\end{array}$ \\
\hline \multirow[t]{5}{*}{ Funding sources variables } & NRNR transfers & $\begin{array}{l}0,109^{*} \\
(0,0643)\end{array}$ & $\begin{array}{l}0,133^{* * *} \\
(0,0353)\end{array}$ & $\begin{array}{l}0,0673^{* * *} \\
(0,0159)\end{array}$ \\
\hline & NRNR transfers $(-1)$ & $\begin{array}{l}0,131^{* *} \\
(0,0570)\end{array}$ & $\begin{array}{l}0,150^{* * *} \\
(0,0357)\end{array}$ & $\begin{array}{l}0,0248^{*} \\
(0,0143)\end{array}$ \\
\hline & Capital transfers & $\begin{array}{l}0,0286^{* * *} \\
(0,00913)\end{array}$ & $\begin{array}{l}0,0341^{* * *} \\
(0,00467)\end{array}$ & $\begin{array}{l}0,0538^{* * *} \\
(0,00168)\end{array}$ \\
\hline & Credit operations & $\begin{array}{l}0,0139^{*} \\
(0,00790)\end{array}$ & $\begin{array}{l}0,00119 \\
(0,00346)\end{array}$ & $\begin{array}{l}0,0117^{* * *} \\
(0,00223)\end{array}$ \\
\hline & Directly collected resources & $\begin{array}{l}0,160 \\
(0,246)\end{array}$ & $\begin{array}{l}0,0369 \\
(0,0389)\end{array}$ & $\begin{array}{l}0,0576^{* * *} \\
(0,0107)\end{array}$ \\
\hline \multirow[t]{5}{*}{ Management capacity variables } & Technical assistance & $\begin{array}{l}-0,122 \\
(0,0941)\end{array}$ & $\begin{array}{l}-0,0693 \\
(0,0470)\end{array}$ & $\begin{array}{l}-0,0296 \\
(0,0219)\end{array}$ \\
\hline & Training requirement & $\begin{array}{l}0,0753 \\
(0,0959)\end{array}$ & $\begin{array}{l}0,0340 \\
(0,0422)\end{array}$ & $\begin{array}{l}-0,0622^{* * *} \\
(0,0219)\end{array}$ \\
\hline & Internet access & & $\begin{array}{l}0,222^{* *} \\
(0,0988)\end{array}$ & $\begin{array}{l}0,0379 \\
(0,0299)\end{array}$ \\
\hline & Reelection & $\begin{array}{l}0,270^{*} \\
(0,142)\end{array}$ & $\begin{array}{l}0,174^{* *} \\
(0,0750)\end{array}$ & $\begin{array}{l}0,211^{* * *} \\
(0,0422)\end{array}$ \\
\hline & Experience & $\begin{array}{l}0,0176 \\
(0,0241)\end{array}$ & $\begin{array}{l}0,00999 \\
(0,0111)\end{array}$ & $\begin{array}{l}0,00667 \\
(0,00683)\end{array}$ \\
\hline \multirow[t]{3}{*}{ Political budget cycle } & Year1 & $\begin{array}{l}-0,293^{* * *} \\
(0,106)\end{array}$ & $\begin{array}{l}-0,178^{* * *} \\
(0,0515)\end{array}$ & $\begin{array}{l}-0,304^{* * *} \\
(0,0278)\end{array}$ \\
\hline & Year2 & $\begin{array}{l}-0,0169 \\
(0,0814)\end{array}$ & $\begin{array}{l}0,0929^{* *} \\
(0,0361)\end{array}$ & $\begin{array}{l}0,00216 \\
(0,0199)\end{array}$ \\
\hline & Year3 & $\begin{array}{l}0,00796 \\
(0,0673)\end{array}$ & $\begin{array}{l}-0,0299 \\
(0,0275)\end{array}$ & $\begin{array}{l}-0,136^{* * *} \\
(0,0194)\end{array}$ \\
\hline \multirow[t]{7}{*}{ Control variables } & Non-primary GDP & $\begin{array}{l}-0,0400 \\
(0,294)\end{array}$ & $\begin{array}{l}0,129 \\
(0,215)\end{array}$ & $\begin{array}{l}0,312^{* * *} \\
(0,0700)\end{array}$ \\
\hline & Urban & & $\begin{array}{l}-1,035 \\
(3,854)\end{array}$ & $\begin{array}{l}0,620^{* *} \\
(0,286)\end{array}$ \\
\hline & Access to potable water & $\begin{array}{l}0,597 \\
(8,056)\end{array}$ & $\begin{array}{l}-2,719 \\
(2,478)\end{array}$ & $\begin{array}{l}1,004 \\
(1,176)\end{array}$ \\
\hline & Access to public lighting & & $\begin{array}{l}6,436 \\
(4,148)\end{array}$ & $\begin{array}{l}3,575^{* *} \\
(1,781)\end{array}$ \\
\hline & Constant & $\begin{array}{l}7,851 \\
(10,06)\end{array}$ & $\begin{array}{l}-0,310 \\
(4,952)\end{array}$ & $\begin{array}{l}-3,362 \\
(2,658)\end{array}$ \\
\hline & Observations & 575 & 3268 & 11994 \\
\hline & Number of local governments & 64 & 365 & 1367 \\
\hline
\end{tabular}

Notes: Standard errors corrected by Windmeijer (2005) are in parenthesis.

$* * *, * *$ and $*$ denote significance to 1,5 and 10 percent, respectively. (-1) indicates a lagged variable from previous year.

little bit of mixed results. The reelection variable still has a positive and significant coefficient, reaffirming the impact of municipal reelection on local public investment, whereas the experience variable is found to be non-significant despite having the expected positive sign. Other variables such as technical assistance, training requirement and internet access also exhibit non-significant 
coefficients. Finally, regarding the political budget cycle, we find a negative and significant coefficient for the first year after municipal elections across all three groups. However, for variables year2 and year3, coefficients are found to be non-significant. Regardless of the local government size, public investment falls the first year of mandate.

Our main results are shown to be robust to most alternative estimations. Funding sources are regarded as the most important drivers for local public investment and this importance does not seem to change in any specification. Management capacity variables seem important in our baseline estimations, but significance of some variables is sample dependent. Surprisingly, the reelection variable is found to be robust in all exercises. Political budget cycle effects are present in every estimation as public investment plummets every year following municipal elections. Specific dynamics for the following years indicate a rebound the second year of mandate and a slightly lower public investment in the third year compared to the fourth. However, magnitude and significance of these effects can change across some estimations.

\section{Conclusions and Policy Recommendations}

Empirical results from this paper show that the availability of funding sources; management capacities; and the behavior of local authorities according to the political budget cycle are the main public investment drivers in Peru, affecting local public investment in different ways.

Regarding the political budget cycle, our results confirm that local public investment tends to increase during the year when municipal elections take place to then plummet the following year, when new local authorities start a new administration. Interestingly, reelected local governments cushion this downfall because they do not have to go through a steep learning curve again. As local reelection banning is in force since 2018, all new administrations will have to go through a learning curve. Therefore, it is important to ensure that new local authorities will be accompanied the year after municipal elections, in order to strengthen their management capacities and cushion the contraction of public investment. ${ }^{18}$

In relation to the availability of funding sources, NRNR transfers are found to have the greatest impact on local public investment. This result is even more important in medium and small local governments as these tend to depend more on NRNR transfers. This result should call for reflection as the heterogeneous distribution of these resources leads to accentuate the horizontal fiscal imbalances among local governments. Furthermore, the volatility of NRNR transfers is passed down to public investment, which reduces predictability and prevents adequate planning by the local authorities. In this context, stabilization mechanisms such as a rainy day fund ${ }^{19}$ could be useful tools to reduce the variability of this type of transfers.

Other funding sources such as capital transfers are also found to be an important determinant of local public investment, especially for small local governments. We recommend that these transfers must be strategically planned, transparent and predictable, seeking to reduce existing infrastructure gaps rather than following discretionary policies.

\footnotetext{
${ }^{18}$ Measures such as those laid down in Legislative Decree 1404, which implements actions to accompany the new local authorities by the ministries and entities of the executive power, would go along this line.

${ }^{19}$ For more detail, see Fiscal Council (2017).
} 
About directly collected resources, estimated coefficients are found to be high as they could be correlated with other effects related to the management capacity which are not captured in the set of variables used. Results also show that directly collected resources have a greater impact in larger local governments, who have the capacities and infrastructure to raise taxes and other non-tax revenues. In this sense, public policies should promote measures to increase local tax revenues, which is known to be a stable funding source across time.

Concerning the management capacity, we recognize that the variables used in our analysis are limited and not necessarily the most adequate to fully reflect these capacities. However, we can interpret our results as in Aragón and Casas (2009), who point out that that local governments that declared to need technical assistance do so because they do not have adequate technical capabilities to do the entire investment cycle by themselves. In the same manner, the significance of our experience variable reflects the fact authorities acquire capabilities with time.

Finally, we consider that complementary analysis could strengthen our conclusions. Among these we suggest: (i) the inclusion of variables that show more accurately the management capacities, as it is necessary to collect data of higher quality than currently available; (ii) taking into account the effect of neighboring local governments public investment or spatial correlation, as public investment from one local government could be complementary to surrounding local governments; and (iii) the inclusion of regional governments, whose dynamics could differ from local governments in financing sources and assigned competencies. 
Appendix A - The Importance of Local Public Investment in Peru

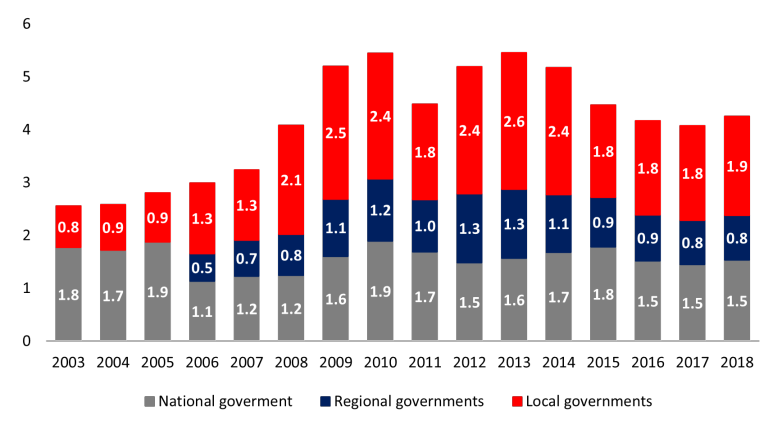

(a) Percentage of GDP.

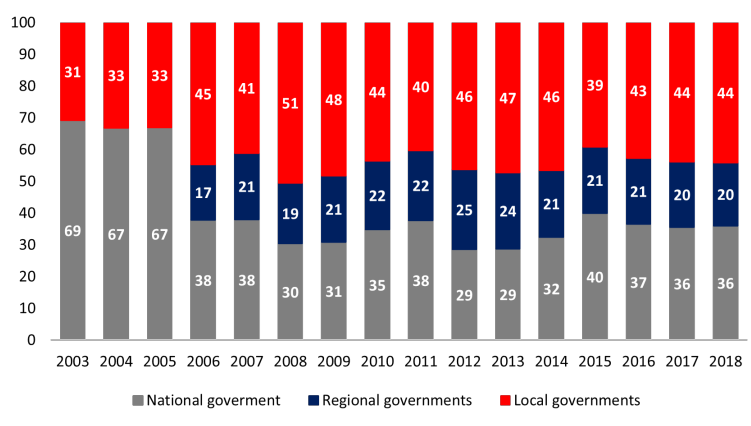

(b) Percentage of total public investment.

Source: Central Bank of Reserve of Peru (BCRP).

Figure A.1. Public investment by government level.

Appendix B - The Features of Local Public Investment

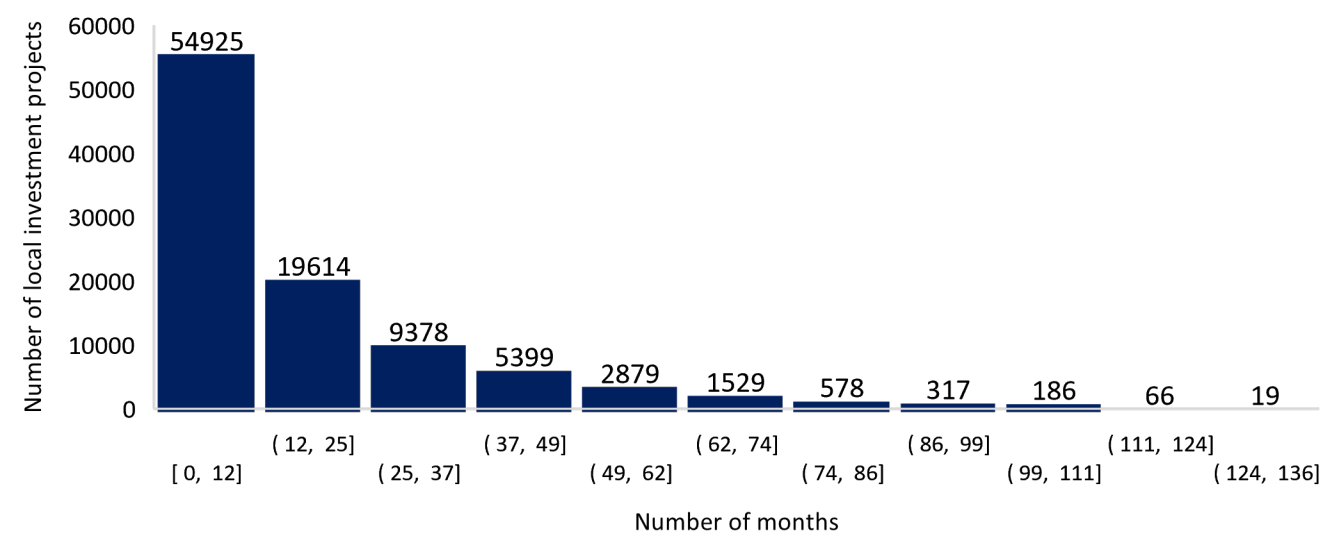

Source: Peru's Ministry of Economic and Finance (MEF).

Figure B.1. Duration of local public investment projects. 


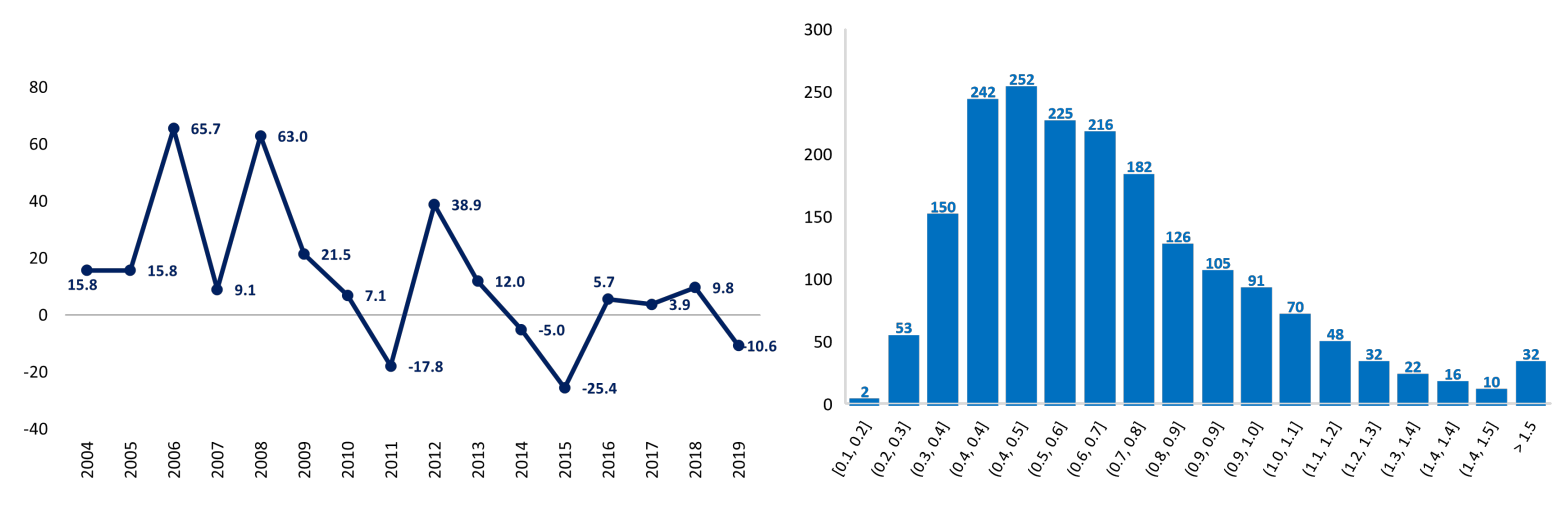

(a) Aggregate growth (annual percentage change in real terms).

(b) Coefficient of Variation by local government (2009-2018).

Source: BCRP and MEF.

Figure B.2. Local public investment variability.

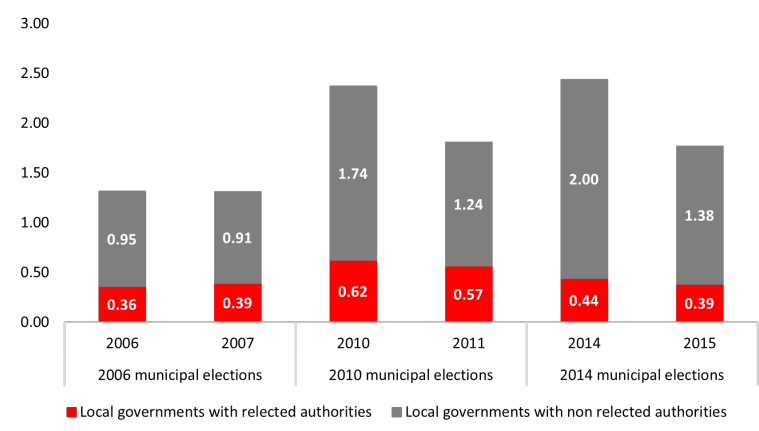

Source: BCRP and MEF.

Figure B.3. Local public investment and political budget cycles (percentage of GDP).

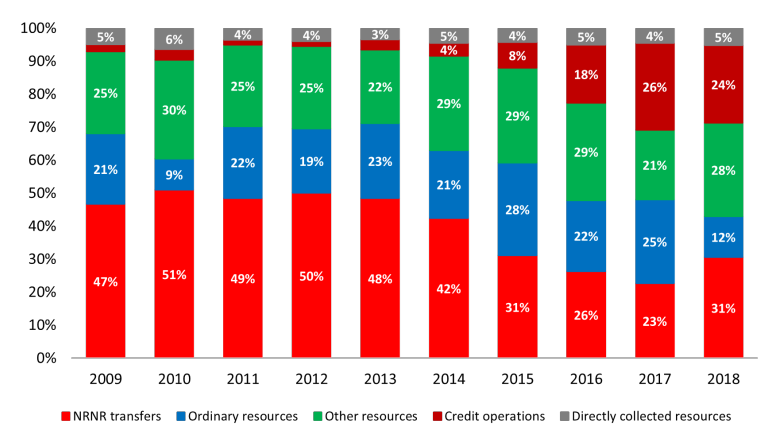

Note: Other resources include grants and transfers, FONCOMUN, customs duties participation, among others. Source: MEF.

Figure B.4. Local public investment financing sources (percentage of total). 


\section{Appendix C - The Funding Sources of Public Investment in Peru}

The 1874 local governments in Peru have different funding sources for public investment. Throughout the document, the funding sources are categorized as follows:

a) Directly Collected Resources

They are those whose collection and administration is carried out by the local government itself. In this category, we have taxes (property taxes and excises mainly), non-tax revenues (fees and contributions) and the sale of capital assets.

b) Non-Renewable Natural Resource Transfers

It is composed mainly by the six types of canon associated to mining, oil, hydroelectric, gas, fishing, and forestry activities; royalties (obtained from the selling of oil and gas); and Fondo de Desarrollo Socioeconómico de Camisea (FOCAM) transfers.

These resources although are collected by the National Government, they are transferred to local governments as compensation for the negative externality generated by the extraction of non-renewable natural resources (Brosio, 2006). Furthermore, according with Peruvian law (article 77 of the Political Constitution of Peru and the article 6 of the Law 27506), these resources can only be used for public investment, under the premise that arise from the use of an asset (non-renewable natural resource), these should serve to generate new assets (infrastructure).

c) Capital Transfers

These transfers serve to cover investment gaps that cannot be financed by other transfers or for specific needs. They are approved each year in the budget law of the public sector and are usually determined on a discretionary basis.

d) Credit Operations

These resources are obtained from the financial system, such as bank loan and bond placement. The budget law establishes a limit for the indebtedness of local governments.

e) Other Resources

They are made up of those transfers that are made according to a law and they cannot classify in any of the other groups described above. Here we have a lot of transfers, the main transfer is called Fondo de Compensación Muncipal (FONCOMUN), that arises from the collection of VAT revenues by the central government. Other transfers inside this group are transfers for the incentive plan for municipality management, customs duties participation, among others.

The preferences for certain funding sources are determined mainly by two characteristics that are defined by the Peruvian laws: i) the obligation to use the resources exclusively for public investment and ii) the possibility of having an excess of resources that can be used in the following 
years (called saldos de balance ${ }^{20}$ ). We can characterize the funding sources according to these characteristics, as shown in the Table C.1.

Table C.1. Classification of funding sources of public investment.

\begin{tabular}{|c|l|l|l|}
\cline { 3 - 4 } \multicolumn{2}{c|}{} & \multicolumn{2}{c|}{ Does it generate saldos de balance? } \\
\cline { 3 - 4 } & & \multicolumn{1}{c|}{ Yes } \\
\hline \multirow{3}{*}{$\begin{array}{c}\text { No } \\
\text { Without } \\
\text { limitation }\end{array}$} & & $\begin{array}{l}\text { Directly collected resources } \\
\text { (taxes, fees, contributions, sale of } \\
\text { assets, among others). } \\
\text { Other resources } \\
\text { (FONCOMUN transfer, customs duties } \\
\text { participation, grants, among others). }\end{array}$ \\
\hline & & $\begin{array}{l}\text { NRNR transfers } \\
\text { (canon, royalties and FOCAM transfers) } \\
\text { Credit operations }\end{array}$ \\
\hline
\end{tabular}

Source: Law of the National Budget System.

\footnotetext{
${ }^{20}$ Saldos de balance are resources that have not been used until December 31 of the relevant fiscal year. It can be incorporated during the execution of the budget of the entity in the following years, in the form of greater public funds that are generated by the increase of the budgetary credits (Law 28411, General Law of the National Budget System).
} 


\section{Bibliography}

Aragón, F. and Casas, C. (2009). Capacidades técnicas y gasto local: el caso de las municipalidades peruanas. Perspectivas: Análisis de temas críticos para el desarrollo sostenible 7(1), 89-113.

Arellano, M. and Bond, S. (1991). Some Tests of Specification for Panel Data: Monte Carlo Evidence and an Application to Employment Equations. The Review of Economic Studies 58(2), 277-297.

Arellano, M., and Bover, O. (1995). Another look at the instrumental variable estimation of error-components models. Journal of Econometrics 68(1), 29-51.

Baltagi, B. H. (2013). Econometric analysis of panel data. Chichester, UK: John Wiley \& Sons.

Balaguer-Coll, M., Brun-Martos, M., Forte, A. and Tortosa-Ausina, E. (2015). Local governments' re-election and its determinants: New evidence based on a Bayesian approach. European Journal of Political Economy 39, 94-108.

Balmas, A. (2015). Determinants of Public Spending at the Subnational Level: a comparison of Polish and Spanish Local Governments (Magister Thesis). ISCTE Business School. Lisboa-Portugal.

Blundell, R. and Bond, S. (1998). Initial conditions and moment restrictions in dynamic panel data models. Journal of Econometrics 87(1), 115-143.

Brosio, G. (2006). The assignment of revenue from natural resources. In E. Ahmad and G. Brosio (Eds.). Handbook of fiscal federalism (chapter 17). Edward Elgar Publishing.

Chortareas, G., Logothetis, V. and Papandreou, A. (2016). Political budget cycles and reelection prospects in Greece's municipalities. European Journal of Political Economy 43, 1-13.

Díaz, R. (2018). Demanda precaria por infraestructura descentralizada y desigualdad rural: desigualdades e inequidades en el mundo rural. In R. Fort, M. Varese y C. de los Ríos (Eds.). SEPIA XVII, Perú: el problema agrario (pp. 495-542). Grupo de Análisis para el Desarrollo (Grade).

Drazen, A. and Eslava, M. (2010). Electoral manipulation via voter-friendly spending: Theory and evidence. Journal of Development Economics 92(1), 39-52.

Fiscal Council (2017). Análisis del nuevo Marco de la Responsabilidad y Transparencia Fiscal (MRTF). Reporte técnico N001-2017-CF/ST. Lima-Perú.

Goeminne, S. and Smolders, C. (2014). Politics and Public Infrastructure Investments in Local Governments: Empirical Evidence from Flemish Municipalities (1996-2009). Local Government Studies 40(2), 182-202.

Guo, G. (2009). China's Local Political Budget Cycles. American Journal of Political Science 53(3), 621-632.

Guzmán, J. (2015). El impacto de las inversiones municipales en la probabilidad de reelección de los alcaldes a nivel distrital en el Perú (Magister Thesis). Universidad del Pacífico. Lima-Perú.

Harris, R. D. F. and Tzavalis, E. (1999). Inference for unit roots in dynamic panels where the time dimension is fixed. Journal of Econometrics 91(2), 201-226. 
Hashem, M. (2015). Time Series and Panel Data Econometrics. Oxford: Oxford University Press.

Hausman, J. and Taylor, W. (1981). Panel data and unobservable individual effects. Econometrica $49(6), 1377-1398$.

Jiménez, A., and Montoro, C. (2018). Identificando el riesgo fiscal de los gobiernos subnacionales en el Perú. Revista Estudios Económicos 35(1), 83-102.

Lastra, J. (2017). Perú: factores determinantes de la inversión pública en los gobiernos locales, periodo 2008-2014 (Magister Thesis). Pontificia Universidad Católica del Perú. Lima-Perú.

Nordhaus, W. D. (1975). The Political Business Cycle. The Review of Economic Studies 42(2), 169.

Pebe, C., Radas, N. and Torres, J. (2017). Canon minero y ciclo político presupuestal en las municipalidades distritales del Perú, 2002-2011. Revista CEPAL 123, 181-199.

Reid, B. G. (1998). Endogenous elections, electoral budget cycles and Canadian provincial governments. Public Choice 97, 35-48.

Rogoff, K. (1990). Equilibrium Political Budget Cycles. American Economic Association 80(1), 21-36.

Rogoff, K. and Sibert, A. (1988). Elections and Macroeconomic Policy Cycles. The Review of Economic Studies 55(1), 1-16.

Rojas, C. and Vassallo, R. (2018). Posición fiscal y ciclo económico. Nota de discusión № 0012018-CF/ST. Lima.

Schneider, C. J. (2010). Fighting with one hand tied behind the back: Political budget cycles in the West German states. Public Choice 142(1), 125-150.

Shi, M. and Svensson, J. (2006). Political budget cycles: Do they differ across countries and why? Journal of Public Economics 90(8-9), 1367-1389.

Torero, M. and Valdivia, M (2002). La Heterogeneidad de las Municipalidades y el Proceso de Descentralización en el Perú. Grupo de Análisis para el Desarrollo (Grade).

Veiga, L. G. and Veiga, F. J. (2007). Political business cycles at the municipal level. Public Choice 131(1-2), 45-64.

Windmeijer, F. (2005). A finite sample correction for the variance of linear efficient two-step GMM estimators. Journal of Econometrics 126(1), 25-61. 